\title{
Effect of Land Clearing Activity on Environmental and Arthropods Diversity (Case Study: Jati Agung, Lampung)
}

\author{
David Septian Sumanto Marpaung1, Nova Anika1*, Yazid Bindar² \\ ${ }^{1}$ Department of Biosystems Engineering, Institut Teknologi Sumatera, South Lampung, Indonesia \\ 2Department of Chemical Engineering, Institut Teknologi Bandung, Bandung, Indonesia
}

\begin{abstract}
Agricultural activity relies on soil as their growth media. Besides agricultural activity, other living species also needs soil as their ecosystem. However, the biodiversity and environmental factor are often neglected in agricultural activity. Therefore, the investigation of environmental and biodiversity changes is important. In this study, the environmental parameter and biodiversity changes was investigated in area after land clearing activity. The $\mathrm{pH}$ was increased from in 3 times measurement. Besides, the soil temperature and air temperature was also increased in 3 times measurement between pre- and post-treatment. The soil temperature ranges from $26.2{ }^{\circ} \mathrm{C}$ to $33.2{ }^{\circ} \mathrm{C}$ in pre-treatment and $27.6{ }^{\circ} \mathrm{C}$ to $31.8{ }^{\circ} \mathrm{C}$ in post-treatment. The air temperature was observed ranges from $27.96{ }^{\circ} \mathrm{C}$ to $34.3{ }^{\circ} \mathrm{C}$ in pre-treatment and $28.36{ }^{\circ} \mathrm{C}$ to $34.56{ }^{\circ} \mathrm{C}$ in post-treatment. Measurement of RH was resulted ranges from $61.2 \%$ to $75.4 \%$ in pre-treatment and $61.4 \%$ to $74.8 \%$ in pre-treatment. The land is proposed become paddy field for next step land processing. As result, the diversity index was decreased in pre- and posttreatment. The Shannon diversity index was decreased from 0.81 to 0.72 . Similarly, the Simpson diversity index was also decreased from 1.94 to 1.77. Meanwhile, the evenness index was increased from 0.58 to 0.65 . These results suggested for farmer to process the land as soon as possible after land clearing process, if they want to form paddy field from pasture land.
\end{abstract}

Keywords: Biodiversity, Land Clearing, Soil, Environmental

\begin{abstract}
ABSTRAK
Kegiatan pertanian bergantung pada tanah sebagai media tumbuh suatu tanaman. Selain kegiatan pertanian, organisme hidup lain juga bergantung terhadap tanah sebagai ekosistem. Namun, seringkali biodiversitas dan faktor lingkungan diabaikan dalam kegiatan pertanian. Oleh karenanya, indentifikasi perubahan lingkungan dan biodiversitas sanget perlu dilakukan. Dalam penelitian ini, perubahan parameter lingkungan dan biodiversitas diamati sebelum dan sesudah aktivitas land clearing. Hasil pengamatan menunjukkan, pH tanah, suhu tanah dan suhu lingkungan meningkat dalam 3 kali pengukuran dari sebelum ke sesudah aktivitas land clearing. Suhu tanah berkisar $26.2{ }^{\circ} \mathrm{C}-33.2{ }^{\circ} \mathrm{C}$ pada sebelum kegiatan land clearing dan $27.6{ }^{\circ} \mathrm{C}-31.8{ }^{\circ} \mathrm{C}$ setelah aktivitas land clearing. Suhu lingkungan ditemukan berkisar $27.96{ }^{\circ} \mathrm{C}-34.3{ }^{\circ} \mathrm{C}$ pada kegiatan sebelum land clearing dan $28.36{ }^{\circ} \mathrm{C}-34.56{ }^{\circ} \mathrm{C}$ setelah kegiatan land clearing. Hasil pengukuran RH lingkungan ditemukan berkisar $61.2 \%-75.4 \%$ pada kegiatan sebelum land clearing dan 61.4\%-74.8\% setelah kegiatan land clearing. Sementara itu, index diversitas ditemukan menurun setelah aktivitas land clearing. Nilai Shannon diversity index ditemukan menurun setelah aktivitas land clearing dari 0.81-0.72. Pola serupa ditemukan pada nilai Simpson diversity index, dimana terjadi penurunan dari 1.94 menjadi 1.77. Nilai evenness index meningkat dari 0.58 menjadi 0.65 . Berdasarkan hasil tersebut dapat disarankan ke petani untuk segera mengolah lahan tersebut setelah kegiatan land clearing untuk menghindari terjadinya pertumbuhan kembali vegetasi, serta perubahan parameter lingkungan dan biodiversitas.
\end{abstract}

Kata Kunci: Biodiversitas, Land Clearing, Tanah, Lingkungan

Citation: Marpaung, D., Anika, N., dan Bindar, Y. (2021). Effect of Land Clearing Activity on Environmental and Arthropods Diversity (Case Study: Jati Agung, Lampung). Jurnal Ilmu Lingkungan, 19(2), 444-449, doi:10.14710/jil.19.2.444-449

\section{Introduction}

Soil has recently been described as the world's most dynamic and abundant ecosystem. The agricultural activity relies on quality of soil, in order to fulfill the food and energy demand. Soil is also represents an important component of biodiversity in ecosystems. Around $25 \%$ of the living species on this earth are found in the soil, and the importance of this biodiversity in relation to its operating roles in ecosystem processes have already been explained (Geisen et al., 2019). However, the biodiversity of soil organisms is often neglected. The agricultural actor is normally skipped to keep the soil biodiversity, which is resulted environmental damage. Therefore, biodiversity aspect must become concern in agricultural activity.

\footnotetext{
* Corresponding author: nova.anika@tbs.itera.ac.id
} 
Land clearing was one of agricultural activity in conversion from pasture land become certain agriculture commodity land. Land use transition represents the single largest threat to biodiversity and ecosystems worldwide due to the resulting habitat destruction, fragmentation, and depletion (Vié et al., 2009). Extensive vegetation tracts are important for the facilitation and tracking of resources that are seasonally or interannually changing in species (Soulé et al., 2004). Therefore, biodiversity issue is important in land transition activity.

In Institut Teknologi Sumatera (Lampung) area, there are many pasture unused land. Conversion unused land needs land clearing with heavy equipment, such as excavator. As land clearing activity must be keep the biodiversity issue, therefore track the environmental and biodiversity changes will be significant activity to the sustainability. In this study, the environmental and arthropods changes caused by land clearing activity will be observed. The aim of this study was to investigate the effect of land clearing on environmental and arthropods in unused land.

\section{Methods}

\subsection{Time and site}

The research was conducted from August to November 2020 in Institut Teknologi Sumatera area, which is located in South Lampung, Lampung. The location of this study is seen in Figure 1. There is a retention basin near location of this study. The land was cleared by excavator (Figure 2) for further processing becomes paddy field.

\subsection{Environmental Parameter Measurement}

In order to know the environmental condition of this study site, several parameters were measured, such as temperature, relative humidity $(\mathrm{RH})$, and $\mathrm{pH}$. The temperature and $\mathrm{RH}$ of air were measured by Thermohygrometer (Krisbow KW06-797). Meanwhile, the temperature and $\mathrm{pH}$ of soil were measured by soil tester (i-tuin). The environmental parameter measurement was conducted in 5 different site and 3 different time, including 08.00 AM, 12.00 AM and 06.00 PM.

\subsection{Sample Collection}

To know the amount of insect species in soil, sampling and insect identification were applied in this study. The samplings were done overnight using a pit fall trap with diameter $7 \mathrm{~cm}$ and height $25 \mathrm{~cm}$. The plot area of this study was $50 \times 100 \mathrm{~m}$ with 5 sub-areas. The five sub-areas were picked diagonally, four on the outer side and one in the center of each plot. The samples were obtained at least one meter from the edge of each plot to reduce the edge impact. The arthropods were sampled at pre-clearing and post clearing area. All sampled were kept in plastic bottles containing detergent and were brought to the Biosystems Engineering Laboratory, Institut Teknologi Sumatera for further identification. The collected samples were then identified. Individual number of each Arthropod category was calculated to define its population.

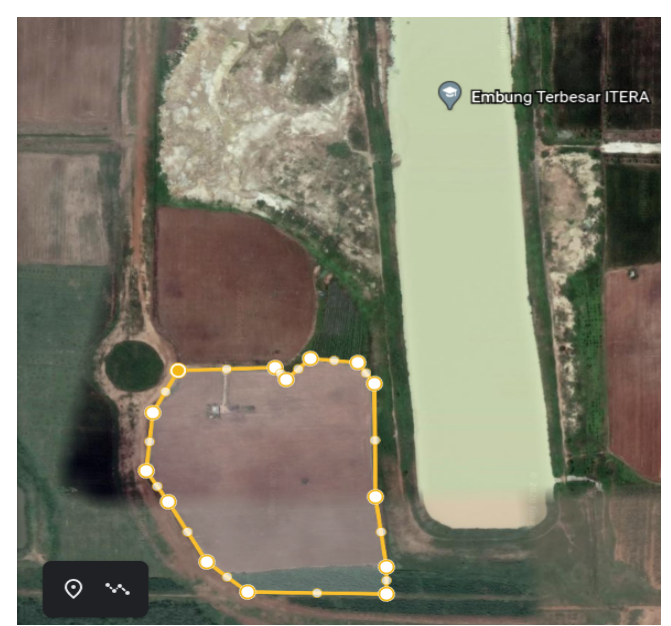

(b)

(a)

Figure 1. Site location of this study; (a) Location map, (b) Detail location of this study. 


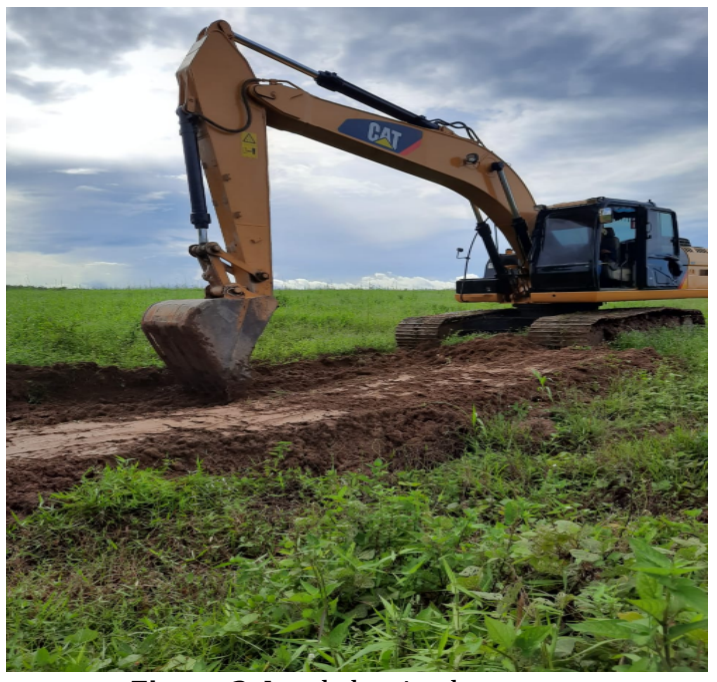

Figure 2. Land clearing by excavator

\subsection{Analysis of Diversity Index}

To know the diversity in soil, several diversity index formula were used in this study. The equation of Shannon-wiener diversity index was:

$$
H^{\prime}=-\sum_{i=1}^{S} p_{i} \ln p_{i}
$$

Where, $\mathrm{H}^{\prime}=$ Diversity index, pi = number of an individual/total individual species.

After the diversity index was calculated, then the evenness index was quantify follow this equation:

$$
E_{H}=H / \ln S
$$

Where, $\mathrm{H}=$ Diversity index, $\mathrm{S}=$ number of species

In order to ensure the diversity index, another diversity index formula was used in this study. Simpson's diversity equation was:

$$
D_{s i m}=\sum_{i=1}^{S}\left(\frac{n_{i}\left(n_{i}-1\right)}{N(N-1)}\right)
$$

Where, $\mathrm{D}=$ Diversity index, $\mathrm{S}=$ number of species, $\mathrm{ni}=$ the abundance of the nth species, $\mathrm{N}=$ total abundance of species

\subsection{Data Analysis}

Three replications data collections were used in this study for pre and post- treatments. The mean and standard deviation was used to know the variation of data. A t-test was used to determine whether the difference in environmental changes of land clearing treatment.

\section{Results and Discussions}

\subsection{Envinronmental Changes Caused by Land Clearing}

The land clearing was conducted by excavator for 7 days in Institut Teknologi Sumatera area. In Figure 3 shows the difference apparent pre and post treatment. Land clearance is the practice of removing branches, stumps, brushes, stones and other barriers from the field needed to expand the size of the crop producing the land base of an established farm or to provide land for a new farm operation. In this study, the main purpose of clearing the pasture area is to establish a new paddy field. The land clearing, as the first step in land conversion, become important action for vegetation removal, which is normally store many weed and insect.

In order to know the impact of land clearing to the environment, several environment parameters was measured. The measurement of environmental parameters was observed at 3 different time, 08.00 AM, 12.00 AM, and 06.00 PM. As results showed in Table 1, there are several parameter in pre and post treatment was changed. As showed, the $\mathrm{pH}$ was increased from in 3 times measurement. Besides, the soil temperature and air temperature was also increased in 3 times measurement between pre- and post-treatment. The soil temperature ranges from $26.2^{\circ} \mathrm{C}$ to $33.2^{\circ} \mathrm{C}$ in pretreatment and $27.6^{\circ} \mathrm{C}$ to $31.8^{\circ} \mathrm{C}$ in post-treatment. The air temperature was observed ranges from $27.96^{\circ} \mathrm{C}$ to $34.3{ }^{\circ} \mathrm{C}$ in pre-treatment and $28.36{ }^{\circ} \mathrm{C}$ to $34.56{ }^{\circ} \mathrm{C}$ in post-treatment, while the average air temperature of Jati Agung according to www.accuweather.com ranges from $24{ }^{\circ} \mathrm{C}$ to $33^{\circ} \mathrm{C}$ at the time of measurement. Measurement of $\mathrm{RH}$ was resulted ranges from $61.2 \%$ to $75.4 \%$ in pre-treatment and $61.4 \%$ to $74.8 \%$ in pretreatment. The t-test value of environmental changes caused by land clearing was showed in Table 1 . The ttest value of environmental changes data was indicated the differences environmental parameters between pre- and post-processing of the land.

The increased of $\mathrm{pH}$ from pre-treatment to posttreatment was occurred in this study. Previous study on impact of tree clearing on soil $\mathrm{pH}$ and nutrient availability showed that the tree clearing increased $\mathrm{pH}$ significantly. The increase of cleared sites was also highly correlated with concentrations of exchangeable $\mathrm{Ca}, \mathrm{Mg}$, and $\mathrm{Na}$. However, availability of soil nutrients was found decreased in that study (Sangha et al., 2005). Further action in increase the soil nutrient would be important study, since in this study site would be used as paddy field. The increase of soil temperature was followed by increase of air temperature. The higher temperature was found at $12.00 \mathrm{AM}$, as sun rise radiated the soil at that time. One of the important factors that influence soil properties processes involved in plant growth and other organisms are temperature soil (Onwuka and Mang, 2018). AraiSanoh et al (2010) found that high soil temperature before heading is more influential on yield, grain 
quality and plant growth compared with a high temperature during the ripening stage. High soil temperature will increase the tension of high air temperatures. Long-term elevation of soil temperatures above $32^{\circ} \mathrm{C}$ has a detrimental impact on plant growth and yield. Beside give impact to plant, soil temperature was also impact to arthropods in soil. Reduction of soil temperature affect on arthropod population, which live inside soil (Mackay et al., 1986). Good environment will impact on the biotic health (Cahyani et al., 2019; Marpaung etal., 2020). Therefore, keep the soil temperature is important aspect to keep the biodiversity in soil. Whether small scale or large scale clearance, land clearing has impacts the environment significantly. The effects may be irreversible when land clearing is extensive, but when clearing is minimal, the effects may be reversed. The land clearance of an area for agriculture purposes must be done as soon as possible.

\subsection{Arthropod Diversity Changes Caused by Land Clearing}

The arthropods move inside the soils in order to fulfill their food and adapted to their environment. They normaly rely on the remains of living things below the soil. The five arthropods were found in this study, including Black ant (Formicidae), Red ant (Formicidae), Collembola (Tomoceridae), Centipede (Geophilidae), and Diplura (Campodeidae). In total, there were 105 individuals of arthropods collected during pre-clearing and post-clearing of land. The ant was the most arthrophods in this study (Figure 4).

Ants are social insects that have evolved effectively since the Cretaceous period and are classified in a single family, the Formicidae. However, there are still very many species to be found and described. Imperfect classification of some groups, particularly when sibling species are present, exacerbates biodiversity estimations (Folgarait, 1998). Despite of certain species of ants put their dependence on thermoregulation for metabolic heat production, most ant species in their environment are exothermic and track temperature (Penick and Tschinkel, 2008). In tropical agroecosystems, ants constitute an important predator group (Philpott and Armbrecht, 2006). Ants are valuable for conservation assesment because of the overall simplicity with which they may be researched.

There are decreasing pattern of both black ant (from 42 to 28 unit) and red ant (from 24 to 6 unit) (Figure 4). However, the centipede and diplura were found after land clearing. the presence of centipede and diplura in the post land clearing activities is suspected caused by the leftover of vegetation still remain in the location, which become attractive food to such organism. Centipedes are a varied collection of soil invertebrates that perform important roles in terrestrial ecosystems. They are contributing in carbon and nutrient cycling through their feeding process and gut activities which help in litter decomposition (Wang et al., 2018). Meanwhile, diplurans play a vital role in plant litter breakdown and the formation of soil microstructure in hypogean habitats, occupying different trophic levels in the soil as well as cave-ecosystems (Sendra et al., 2021).

The site of study was former rubber plantation, and become unused land for more than 5 years. To utilize such unused land, the land clearing must be applied in this site. The land is proposed become paddy field for next step land processing. As result from Table 2, the diversity index was decreased in pre- and posttreatment. The Shannon diversity index was decreased from 0.81 to 0.72 . Similiarly, the simpson diversity index was also decreased from 1.94 to 1.77. Meanwhile, the evenness index was increased from 0.58 to 0.65 .

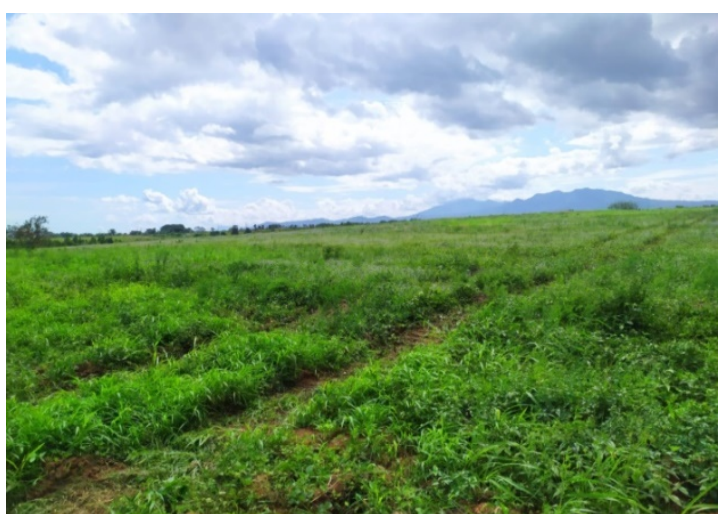

(a)

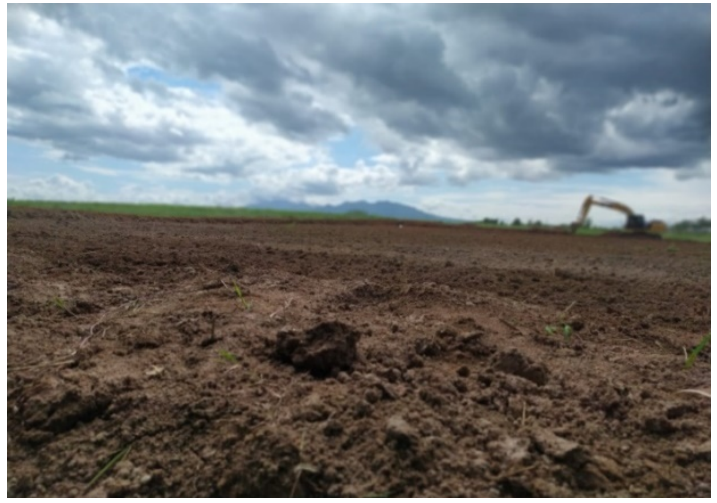

(b)

Figure 3. Land clearing for a new rice field; (a) Pre-treatment, (b) Post-treatment 
Table 1. Comparison of environmental parameter between pre and post treatment

\begin{tabular}{|c|c|c|c|c|c|}
\hline Time & Parameter & $\begin{array}{c}\text { Pre- } \\
\text { processing }\end{array}$ & $\begin{array}{c}\text { Post- } \\
\text { Processing }\end{array}$ & T-value & P-value \\
\hline \multirow{4}{*}{$08.00 \mathrm{AM}$} & Soil pH & $5.90 \pm 0.20$ & $6.40 \pm 0.37$ & -3.16 & 0.034 \\
\hline & Soil Temperature $\left({ }^{\circ} \mathrm{C}\right)$ & $26.20 \pm 0.74$ & $27.60 \pm 0.48$ & -3.50 & 0.025 \\
\hline & Envinronmental Temperature $\left({ }^{\circ} \mathrm{C}\right)$ & $29.48 \pm 0.07$ & $29.64 \pm 0.07$ & -3.14 & 0.035 \\
\hline & Envinromental RH (\%) & $75.40 \pm 1.01$ & $74.80 \pm 1.46$ & 1.5 & 0.208 \\
\hline \multirow{4}{*}{$12.00 \mathrm{AM}$} & Soil pH & $6.10 \pm 0.37$ & $6.60 \pm 0.20$ & -1.83 & 0.142 \\
\hline & Soil Temperature $\left({ }^{\circ} \mathrm{C}\right)$ & $33.00 \pm 0.63$ & $31.80 \pm 0.74$ & 3.21 & 0.033 \\
\hline & Envinronmental Temperature $\left({ }^{\circ} \mathrm{C}\right)$ & $34.30 \pm 0.12$ & $34.56 \pm 0.04$ & -4.33 & 0.012 \\
\hline & Envinromental RH (\%) & $61.20 \pm 0.97$ & $61.40 \pm 1.01$ & -0.34 & 0.749 \\
\hline \multirow{4}{*}{$06.00 \mathrm{PM}$} & Soil pH & $5.80 \pm 0.24$ & $6.80 \pm 0.24$ & -4.47 & 0.011 \\
\hline & Soil Temperature $\left({ }^{\circ} \mathrm{C}\right)$ & $28.40 \pm 0.48$ & $30.40 \pm 0.80$ & -6.32 & 0.003 \\
\hline & Envinronmental Temperature $\left({ }^{\circ} \mathrm{C}\right)$ & $27.96 \pm 0.73$ & $28.38 \pm 0.16$ & -1.01 & 0.370 \\
\hline & Envinromental RH (\%) & $70.60 \pm 0.48$ & $67.00 \pm 0.63$ & 9 & 0.001 \\
\hline
\end{tabular}

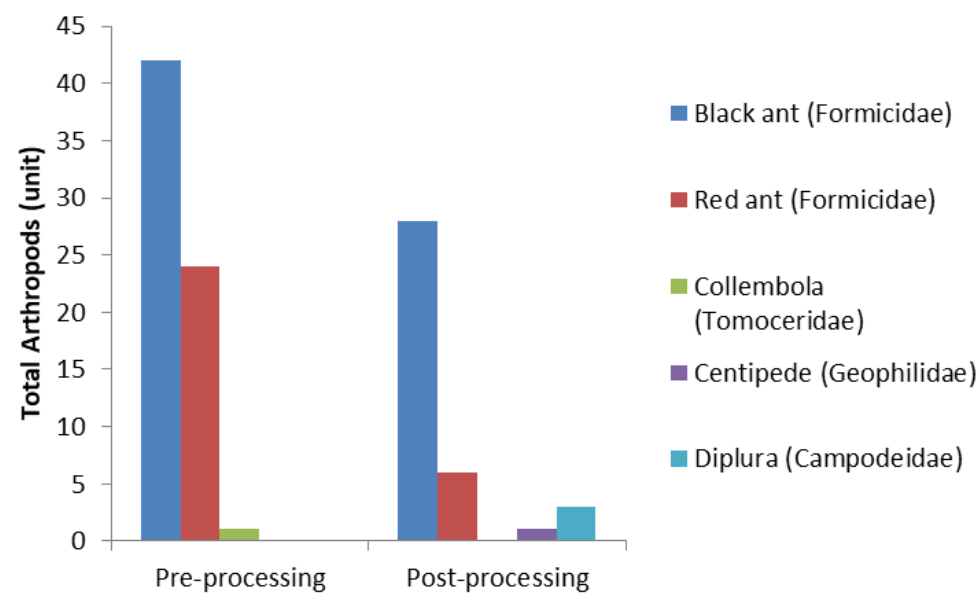

Figure 4. Total arthropods after land clearing

Table 2. The diversity changes various method

\begin{tabular}{lcc}
\hline Index & Pre-Treatment & Post-Treatment \\
\hline Shanonn diversity index & 0.81 & 0.72 \\
Simpson diversity index & 1.94 & 1.77 \\
Evenness & 0.58 & 0.65 \\
\hline
\end{tabular}

Biodiversity refers to the plant range or the number of species found in the area or habitat (Price et al., 2011). The presence of different species of arthropods and their population ecology are important things to be considered when designing pest management methods. In this study, the diversity of arthropods was decreased in cleared area. Both Shanonn and Simpson diversity index showed diversity decreased. The dominant individual species in this study was black ant. Previous study in the Institut Teknologi Sumatera area showed that arthropod diversity loss due to monoculture practice (Darmawan et al., 2019). On landscape changes also showed similar pattern with this study in biodiversity changes, and great influence on trophic and taxonomic structure of habitat type and quality. A less complex landscape had only slightly influence on trophic structure, leading to higher abundance and richness of generalist taxa (Previati et al., 2007). The importance of a multi-taxa approach in understanding biodiversity response to anthropogenic disturbances as well as the value of protected areas in preserving biodiversity (Lingbeek et al., 2017). It indicated that the land clearing is important action in land conversion become paddy 
field. However, uncontrolled condition of land clearing will resulted loss the biodiversity in soil, consequences to soil nutrition. Therefore, keep the biodiversity in land clearing condition will be the new challenges. Mass land clearance has a significant impact on the natural environment not only of the plants and animals living in the area, but also of the local human population. When native plants and trees are replaced, there is space for introduced species to take over which drives the native wildlife out of the area, creating an increase in the risk of extinction.

\section{Conclusion}

The land clearing was resulted environmental changes. Several environmental were changed, including, $\mathrm{RH}$, soil temperature, air temperature and $\mathrm{pH}$. In addition, the environmental changes were followed by arthropods diversity changes. The diversity changes were measured by shanon index and tompson index equation. These results suggested for farmer to process the land as soon as possible after land clearing process, if they want to form paddy field from pasture land.

\section{Acknowledgements}

The research was financially supported by Institut Teknologi Sumatera, through the Guru Besar Under 45 (GBU) Research program with contract number B/405/IT9.C1/PT.01.03/2020

\section{REFERENCES}

Arai-Sanoh, Y., Ishimaru, T., Ohsumi, A., \& Kondo, M. (2010). Effects of soil temperature on growth and root function in rice. Plant Production Science, 13(3), 235-242.

Cahyani, D., Haryanto, A., Putra, G., Fil'aini, R., \& Marpaung, D. (2019). Life cycle assessment of biogas digester in small scale tapioca industry. Paper presented at the IOP Conference Series: Earth and Environmental Science.

Darmawan, A., Wijayanti, H., \& Ariyanti, Y. (2019). Arthropod diversity loss due to monoculture practice in south lampung, indonesia. BioWallacea Jurnal Ilmiah Ilmu Biologi, 5(2), 69-73.

Folgarait, P. J. (1998). Ant biodiversity and its relationship to ecosystem functioning: a review. Biodiversity \& Conservation, 7(9), 1221-1244.

Geisen, S., Briones, M. J., Gan, H., Behan-Pelletier, V. M., Friman, V.-P., de Groot, G. A., Hannula S. E., Lindo Z., Philippot L., Tiunov A. V., Wall D. H. (2019). A methodological framework to embrace soil biodiversity. Soil Biology and Biochemistry, 136, 107536.

Lingbeek, B. J., Higgins, C. L., Muir, J. P., Kattes, D. H., \& Schwertner, T. W. (2017). Arthropod diversity and assemblage structure response to deforestation and desertification in the Sahel of western Senegal. Global ecology and conservation, 11, 165-176.

Mackay, W. P., Silva, S., Lightfoot, D. C., Pagani, M. I., \& Whitford, W. G. (1986). Effect of increased soil moisture and reduced soil temperature on a desert soil arthropod community. American Midland Naturalist, 45-56.

Marpaung, D. S. S., Indriyani, A., Fahadha, R. U., Mardiono, I., \& Haryanto, A. (2020). Determination of Aflatoxin Contamination Risk along Maize Distribution Chain (Case study: A Maize Enterprise in East Lampung). Paper presented at the IOP Conference Series: Earth and Environmental Science.

Onwuka, B., \& Mang, B. (2018). Effects of soil temperature on some soil properties and plant growth. Adv. Plants Agric. Res, 8, 34-37.

Penick, C. A., \& Tschinkel, W. R. (2008). Thermoregulatory brood transport in the fire ant, Solenopsis invicta. Insectes Sociaux, 55(2), 176-182.

Philpott, S. M., \& Armbrecht, I. (2006). Biodiversity in tropical agroforests and the ecological role of ants and ant diversity in predatory function. Ecological entomology, 31(4), 369-377.

Previati, E., Fano, E. A., \& Leis, M. (2007). Arthropods biodiversity in agricultural landscapes: effects of land use and anthropization. Italian Journal of Agronomy, 135-142.

Price, P. W., Denno, R. F., Eubanks, M. D., Finke, D. L., \& Kaplan, I. (2011). Insect ecology: behavior, populations and communities: Cambridge University Press.

Sangha, K. K., Jalota, R. K., \& Midmore, D. J. (2005). Impact of tree clearing on soil $\mathrm{pH}$ and nutrient availability in grazing systems of central Queensland, Australia. Soil Research, 43(1), 51-60.

Sendra, A., Jiménez-Valverde, A., Selfa, J., \& Reboleira, A. S. P. (2021). Diversity, ecology, distribution and biogeography of Diplura. Insect Conservation and Diversity.

Soulé, M. E., Mackey, B. G., Recher, H. F., Williams, J. E., Woinarski, J., Driscoll, D., Dennison W. C., Jones M. E. (2004). The role of connectivity in Australian conservation. Pacific Conservation Biology, 10(4), 266279.

Vié, J.-C., Hilton-Taylor, C., \& Stuart, S. N. (2009). Wildlife in a changing world: an analysis of the 2008 IUCN Red List of threatened species: IUCN.

Wang, M., Fu, S., Xu, H., Wang, M., \& Shi, L. (2018). Ecological functions of millipedes in the terrestrial ecosystem. Biodiversity Science, 26(10), 1051. 